\title{
States, nations, and societies: a case study of Valencia
}

\author{
Rafael Castelló-Cogollos \\ UNIVERSITAT DE VALÈNCIA \\ rafael.castellofuuv.es \\ ORCID: 0000-0002-3481-741X \\ Received: 31/07/2016 \\ Accepted: 22/01/2017
}

\begin{abstract}
Political activity of contemporary western societies has been structured based on a definition of territorial units of action, which we call states. This western political structure has been legitimised by a link between each state to a collective owner of sovereignty, which we call a nation. The life of this society revolves around areas linked to different fields of community life, such as production, consumption, distribution of work, etc., including the discursive elements of these practices. Social practices take place within the complex interaction between all these fields of relations, which we call social structure. Each of these collective forms (states, nations and social structure) outline several geographic and social areas, to facilitate or hinder the construction of certain collective identities and, therefore, facilitate or hinder the production of certain collective actions. In the first part, this article opens a discussion on the relationship between the concepts of state, nation, and social structure. Later, the article endeavours to empirically apply the theoretical discussion to the Valencian case, to reveal the mechanisms underlying the construction of its collective identity.
\end{abstract}

Keywords: state structures, national identity, social structure, Valencia.

Corresponding author: Rafael Castelló. Dep. Sociología y Antropología social (Facultad de Ciencias Sociales) Universitat de València. Avda. Tarongers, 4b, (46021) Valencia.

Suggested citation: Castelló, R. (2017). States, nations, and societies: a case study of Valencia. Debats. Journal on Culture, Power and Society, 2, 33-46. doi: http://dx.doi.org/10.28939/iam.debats-en.2017-3

\section{INTRODUCTION}

On April 8, 2016 a round table discussion was held at the School of Social Sciences at the University of Valencia. Under the title: A plurinational state? Diverse perspectives from the País Valencià, Catalonia, the Basque Country, Navarre and Europe, it called for shared reflection, from different viewpoints, on the situation of and the opinions on a changing political model in Spain, within the European context. I was invited to offer a perspective on the situation in Valencia. This article stems from the written formalisation of that speech.
In the following pages I attempt to summarise the result of multiple research projects carried out over several years with the aim of trying to understand the relationship between the Valencian social structure and the construction of its collective identity. The first part deals with the concepts of state, nation, and how they are interconnected, helping us to channel the empirical observations and standpoints made. The second part applied these ideas to the Valencian case, in an attempt to understand the mechanisms that have played a role in the construction of its identity as part of the Kingdom of Spain. 


\section{THE STATE: TERRITORY AND COMMUNITY}

Throughout history, political communities have evolved from taxation groups to absolute monarchies, and in turn, from the latter into modern states: the result is a wide range of territorial dimensions. As size increases, strength (even if it is through voting) tends to replace consensus: political power tends to hold onto elements of domestic power, but without being mitigated by emotional bonds.

Weber considers that "the state is a human community that (successfully) claims the monopoly of the legitimate use of physical force within a given territory-the concept of 'territory' is essential to the definition" (Weber, 1922, p. 1,056). The state's action is always a territorial action delimited by borders, binding its citizens. The organisational core of the state is comprised by a rational apparatus with a permanent and centralised military power, which monopolises the creation of law and the legitimate use of force, and it organises the administration with a dominance of specialised public officials. From thereon, public administration, territoriality, and community become central components of collective action.

For Marx, the political structure sanctions the social order established through the dominant mode of production: social relations provide an explanation of the state, and not the other way round. The social division of work facilitates the emergence of bureaucracy, with the separation of private interests and general interests, and the split between the private and the public. This split produces a dual life; life in the political community, where the individual is a citizen and is valued as a social being, and life in civil society, where they act as a private person and consider the others as means ('objects'). However, bureaucracy is intended to be the will of the state and state power, and its particular interest is aimed at being general. The State's objectives become those of bureaucracy, and vice versa, without this impenetrable combination excluding conflicts. Thus, the state summarises and represents social conflicts, the needs of society as a whole, expressed through the mode of production, establishing a close connection between social structure and the state.

The state's power is therefore based on the monopoly it holds, whether legitimate or illegitimate, over the use of force. It is a power based on violence, or the threat of using it, in other words, the power to destroy life or to protect it from destruction. However, the state can only exercise its power over a community within the limits of a territory. That is to say, the state is structured around natural elements that give rise to social constructs: in the state, the people and land become the nation and territory (Foucault, 1996, 2006, 2007).

Bourdieu tries to complete the Weberian definition, as the state's power becomes clearly apparent within the realm of symbolic relationships: "the state is an X (to be determined) which successfully claims the monopoly of the legitimate use of physical and symbolic violence over a definite territory and over the totality of the corresponding population" (Bourdieu, 1994, pp. 97-8). This symbolic violence facilitates the concealment of possible alternatives, such as the ultimate expression of power (Lukes, 2005).

That is why, for Habermas (1976, p. 245), the state emerges in order to ensure the identity of the social group, in order to legitimise coercion and in order to achieve social integration more effectively. According to his approach, through binding decisions, the state prevents social disintegration. In order to be maintained and remain effective in the long term, political dominance needs to obtain recognition as the legitimate power, and not only as the legal power.

Thus, in addition to the official apparatus of the government, the components inherent to all states, whether they are traditional or modern, are a territory that delimits the exercise of power and legitimate rights, which provides backing to the decisions made by the government in the territory. The sources of this legitimacy have changed over time, and in Western modernity it is communities which have become 'nations' that assume this legitimising capacity. 


\section{Territoriality}

Territorial action, like all social action, is always aimed at affecting, influencing, or controlling the ideas and actions of others (Weber, 1922, p. 5) and consequently, also their access to resources, which means that territorial relationships are the result of power.

The real political space of relations of domination is defined by the relationship between the dis-tribution of powers and assets within the geographical space, and the distribution of agents within this space, the geographical distance to those assets and powers is a good index of power (Bourdieu, 1980, p. 70).

These territorial divisions have significant effects over who is dominated, by whom, and for what purpose. The creation of a territory produces a special kind of space that, unlike others, requires a constant effort in terms of establishment, maintenance and reproduction (Sack, 1986; Soja, 1985). Whatever the scale, all societies need to engage in territorial activities in order to coordinate efforts and specify responsibilities. Therefore, when we talk about territory, we are talking about a structured series of economic and cultural resources that are established within in the space (infrastructures, industries, social provisions, etc.) which facilitate social functioning, and form the foundation of the mode or production (Harvey, 1985; Rokkan and Urwin, 1983).

Thus, any territorial organisation can oppose the interests and objectives of certain social groups. Territorial behaviour is not only a means of creating and maintaining order, rather, it is a resource for creating and maintaining a context to experience the world through, and give it meaning. The territory is therefore a physical element, defined geographically by its borders, but it is also a symbolic element that affects the definition of the community itself and included in the Weberian concept of a state.

At this juncture in history, the opposition between globalisation and individualisation results in several situations of social confrontation, which the current policy of the state does not appear able to resolve effectively.

The revolution of information technologies and the restructuring of capitalism has produced a new form of society, which is characterised by the globalisation of decisive economic activities from a strategic viewpoint, due to its organisation in networks, flexibility and instability in work and individualisation, through a culture of virtual reality, constructed via an omnipresent system of media that is interconnected and diversified, and the transformation of the core materials of life, space and time, via the creation of a space of flows and timelessness, as expressions of dominant activities and the ruling elites (Castells, 1997, p. 23).

However, there are also expressions of collective identity that challenge this globalisation and individual seclusion in the name of cultural uniqueness and the control people have over their lives and environments. These expressions are manifold, diverse, and follow the cultural contours and path of the historical generation of each of these identities.

\section{Legitimacy: identities and communities}

Identity is a process through which meaning is constructed, along with an objective for action, addressing one or several personal attributes, which are given priority over the other possible sources of meaning (Castells, 1997, from p. 28 onwards). Identity fulfils three main functions: it helps us to take decisions and to make sense of and establish objectives for action: it makes relationships possible with others, by enabling mutual recognition in positions and relationships, and it provides strength and resistance, by giving references for action (Guibernau, 1997, p. 115).

These attributes establish limits between those that have them and those that do not, therefore the fission and fusion of social limits affect individuals in terms of identity. These limits can be contested, 
but not abolished: the disappearance of one always involves the emergence of another (Oommen, 1995). The social significance of specific attributes, which are possessed individually but shared collectively, leads to the emergence of collective identities, which facilitate cohesion between those who share these attributes ('us'), through similarity-based strategies, and distinguish those that do not share said attributes ('them'), through strategies of differentiation or diversification (Barrera-González, 1997, p. 232; Bourdieu, 1979).

Socialisation processes are those constructing correspondence between the social structure and cognitive and symbolic structures (Berger and Luckmann, 1966, p. 205): the correspondence between the objective divisions of the social world and the principles of "vision and division" that the agents apply. Ongoing exposure to specific social conditions imprints long-lasting attitudes on individuals, who interiorise the needs of the social environment and inscribe their outer reality onto their inner being. "Talking about habitus is to suggest that what is individual, and even personal, and what is subjective, is also social and collective. Habitus is a socialised subjectivity" (Bourdieu and Wacquant, 1992, p. 104). This correspondence fulfils eminently political roles, because the symbolic systems are not only instruments of knowledge but also instruments of domination. Recognition of legitimacy is rooted in the harmony between the cognitive structures that become unconscious, and the objective ones.

In the process of constructing collective identities, a path is taken that leads us from diversity and social complexity to public statements about shared identity via mechanisms that Larrain (1994, p. 164) groups into four specific elements:

(1) Selection mechanisms; only some attributes, some symbols, and the social experience of some groups is taken into account, the rest are excluded.

(2) Evaluation mechanisms; the values of certain groups or institutions are presented as general values, while others are disparaged, or simply excluded.
(3) Opposition mechanisms; the ways of life and ideas of certain groups are presented as foreign, strange, not normal, atypical, etc., and, if necessary, these differences are exaggerated.

(4) Naturalisation mechanisms; the previous traits are presented as given, immutable, normal, and natural.

Ultimately, the social effectiveness of a collective identity depends on the capacity to select, evaluate, oppose and naturalise certain characteristics, and not others. It depends on the capacity to impose a way of seeing social reality as truth, regardless of its scientific support. This capacity is not distributed equally among social groups: having power makes it possible to institutionalise a way of seeing and of objectifying this reality.

The objectification of a collective identity occurs, firstly, out of the mutual recognition of individuals, by referring mutually to an 'us', leading simultaneously to the emergence of a 'them' and a 'you'. Secondly, it is objectified through recognition of the group by others. Thirdly, there is the political or institutional objectification, with the provision of formal recognition structures and schemata for linking this identity with that of the others.

It is these objectification processes that can result in conflict. When the first and second coincide, but the third does not, we face a clash of identities or a conflict between identities. At the same time, the existence of these conflicts is a form of objectifying collective identity. This is a conflict based on the non-correspondence between legal recognition and de facto recognition. As Simmel (1908) said, whenever the interests of two elements refer to the same object, the possibility of coexistence depends on whether there is a boundary line that separates them. If the limitation is juridical (in law) it can mean the end of the conflict, if it is based around power (de facto) it may mark the start of conflict. When the first objectification and the second do not coincide, we face identity conflicts or conflicts about identity if 
the definition is questioned socially from within the group, from outside the group, or from both sides of the boundary, the identity is not socially obvious. The identity conflict is a conflict about the collective 'us', between two or more forms of defining reality. In any case, these conflicts regarding identity necessarily contain conflicts between identities.

Therefore, states may be questioned regarding the conflictive nature of the identity that they promote over their territory, and that they aim to be legitimised in order to exercise power. That is to say, states can see their legitimacy questioned due to the emergence of alternative collective territorial political projects.

\section{NATIONS}

It is not clear therefore that the state is a community, as Weber claims. The state is undoubtedly a form of the territorial organisation of political power, which needs legitimisation. It is therefore advisable, as suggested by Connor (1994) and Tivey (1981), to differentiate between the concepts of state and nation. The most detrimental flaw in "scholarly approaches to nationalism lie in the fact that there has been a tendency to use the term nation to denote a territorial legal unity, the state" (Connor, 1994). Its relationships may coincide, when the territory and the community governed by the state overlap, or do not coincide, when a specific territory is home to a community that differs to that which is promoted by the state (Pérez-Agote, 1989, p. 184). That is why Guibernau (1997) asserts that there may be legitimate states and illegitimate states, and Hall (1999) analyses national identities as independent variables in studies on internal or external state policies.

Nations are a phenomenon that belong to the world of the conscience of social agents. They are effective to the extent they are capable of influencing or determining the behaviour of the agents. This capacity depends on the social objectivity achieved, in the sense of what is socially recognised in a shared way. It is therefore a performative category (Pérez-Agote, 1993): its production and reproduction is linked to its capacity for social mobilisation (Máiz, 1997). Ultimately, a nation is an imagined community (Anderson, 1983), formed by a group of individuals that identify between one another on the basis of very different attributes -including territoriality, volition, history, and ethnicity-according to the specific situation, and which is considered the sovereign subject of political power over a territory (Gellner, 1997; Núñez, 1998; Smith, 1989).

It is this nature of exclusionary legitimacy that distinguishes a national identity from a regional identity. A regional community is an identity that is politically subordinated to the identity of the nation state. According to Moreno (1997), what regionalist movements have in common with nationalist ones is their basis in a territorial identity, the existence of a conflict with the state (whether economic, political, or cultural) and the emergence of political and social mobilisation organisations. However, as Pérez-Agote (1995) points out, in order to recognise the legitimacy of state power, regionalisms do not demand the capacity for self-determination, but rather the delegation of the central power to the regional territory. Nevertheless, regional identities, regionalisms, and regional institutions can act as active builders of a national identity: they can generate the perception of shared and different interests and create favourable conditions for the emergence of a nationalist movement (Nuñez, 1998).

\section{SOCIETIES: SOCIAL STRUCTURE}

The construction of national identities presupposes the existence of specific social conditions: in relation to ethnicity (Smith, 1986), social structure (Hroch, 1985), and/or territory (Hechter, 1985). However, obtaining a functioning notion of 'society' for empirical research is difficult, for two main reasons: the difficulty of establishing consistent limits in time and space, and the difficulty of determining whether the limits define a differentiated and coherent social entity (Tilly, 1984, from p. 37 onwards). However, we can make it work with 
the use of the concept of social structure, in the sense of a framework of relations that organises the activities of the parts that form it. In fact, the term social structure is almost always used to refer to the characteristics of groups, as traits that cannot be attributed to individuals. At times it denotes the coherence of social institutions, at others it opposes it, in order to refer to more persistent and organised societal relationships. Although the agents involved are not always aware of its consistency, the structures continue working, regardless of their conscience and desire.

The major theoretical debates of social sciences have focused on the nature of this relationship between individuals and society, and can be summarised in two blocks. A debate about whether social agents are free when they act, or whether they are constrained by external conditioning factors; and a debate about whether structure is conferred by the material characteristics of society, or by its immaterial characteristics. However, the most recent approaches attempt to integrate this duality in order to try to acquire an image that more accurately portrays the complexity of the social and structural dynamic: material and immaterial, voluntaristic and deterministic, all at the same time (Bourdieu, 1977; Giddens, 1984; Sewell, 1992).

Social agents operate simultaneously in several exchange networks: bodies with the ecosystem, the production of goods and services, power and social control, fears and beliefs, where emotional, economic, political and cultural resources are exchanged (Bourdieu and Wacquant, 1992; Villasante, 2000). Among these interrelated areas, the political sphere (with the state as the central institution) plays an especially important role, inasmuch as it has the capacity to formalise the rules for exchange with the other interrelated areas. Social actions are approached as recursive processes, created by social agents, but continuously recreated through multiple structural resources. The continuity of these social practices presupposes reflexivity that is only possible because of the continuity of the practices themselves (Giddens, 1984; Lamo de Espinosa, 1990). The result is contingent and has no specific direction: it seems that the strategies lead nowhere in particular. Fate is uncertain, unclear and risky, and social change has no apparent direction (Therborn, 2000), thus building a society of risk (Beck, 1998). As Sztompka points out (1993, p. 190) "Society appears to be in perpetual and continuous motion [...] any occurrence becomes an event; any agent can act; any state is only a phase in an open process". This does not mean that these processes do not plot out a temporary path and present a historic dimension: ultimately, we do not know where we are going, but we are going somewhere.

The processes of globalisation and individualisation exacerbate this uncertainty: historic uncertainty (globalisation) and biographic uncertainty (individualisation). The effects of this are a reduction in predictability, an increase in antagonisms, a decrease in complementarities, a rise in conflicts...; a situation in which the old institutions fail (Morin, 2004). Ultimately, the result of all this uncertainty is insecurity and a lack of protection: i.e. fear.

\section{SOCIAL STRUCTURE AND NATIONALISMS IN VALENCIA}

Traditionally, human beings have tried to overcome this fear by associating with other humans, as a means of managing it. Let us return to the starting point of this article and ask the question: is the state legitimised by a nation the most suitable form of collective association in this historic context? Whatever the response to this question may be, in order to overcome the nation-state, if applicable, it is necessary for it to first be questioned with an alternative. In the País Valencià, adherence to the political proposal of the Kingdom of Spain has not had a politically significant response. Unlike Catalonia and the Basque Country, up until a few years ago, Valencian disaffection towards Spain was rather symbolic: shown by qualitatively significant social sectors, its quantitative importance was, however, very limited.

The País Valencià shatters the expectations outlined by the main theories on nationalism. It is a society with its own language, which differs from Castilian Spanish, even though language is considered as a cultural 
hallmark with a great capacity for transmitting identity, especially in conflict situations (Ninyoles, 1971). This is also a society that has also very quickly implemented processes to absorb an immigrant population, which according to the primordialist theses, could have generated identification according to origin (Geertz, 1973; Shils, 1957). Furthermore, the economic structure is based on outsourcing which, according the theories of rational choice, would facilitate the presence of a national political conflict (Hechter, 1989; Rogowski, 1985). Moreover, the political decentralisation process of the Kingdom of Spain, with the introduction of the system of autonomous regions or communities, could have reinforced sub-state identities, as an effect of the regional policies themselves (Brubaker, 1996), or as the result of the structure of political opportunities that this new form of territorial organisation offers (Tarrow, 1994).

Nevertheless, it is as if Spain had achieved its objective of creating a Spanish national community in Valencia. As it is frequently pointed out, this is certainly very much the case: from the territories in the Kingdom of Spain, Valencian society is among those that identify most closely with Spain. However, it is also true that the Valencian case is more complex which we should study more deeply to better understand, and to highlight some of the mechanisms that may have helped it reach this level of adhesion.

\section{The Valencian territory}

One of the greatest issues for the progress of a possible alternative policy to the Spanish one in Valencia is the special territorial concentration of a population from the constituency of Alicante (especially in the provincial capital and its area of influence towards the south), which believes its community is not the Valencian community. ${ }^{1}$ Valencian-Spanish unionism is concentrated very

1 The quantitative empirical statements used throughout the article result from multiple empirical studies carried out by the author, with all the surveys on autonomous community, regional, and national identity by the Spanish Centro de Investigaciones Sociológicas (Centre for Sociological Research [CIS]) in Valencia since 1996. significantly in the Alicante region, and is in considerable contrast with Castellón and Valencia, where regionalist positions prevail. So great is the difference, that this territorial fissure causes serious internal cohesion problems in Valencia.

This is one of the effects of provincialisation and the infrastructures policy that the Spanish state has applied in the Valencian region: provincial rupture and negligence in the policy of infrastructures required for Valencian territorial cohesion. Nor should we forget that a significant part of the territory in the south and west of the current autonomous community was incorporated into Valencia and Alicante with the provincialisation of the 19th century, stemming from Castile.

Furthermore, we should add that among the Valencian population there is a high level of identification with the Spanish territory: a territorial identification that involves the full territorial integration of País Valencià into the Kingdom of Spain. The autonomous territorial unit does not exclude the state, but rather complements it; those that most territorially identify with the Valencian territory are also those that identify most with the state territory. Not even Valencian nationalists identify primarily on a territorial level with the autonomous community itself: they are more municipalists than non-autonomists.

Ultimately, the Kingdom of Spain is the politically significant territorial unit for the population of Valencia and, furthermore, there is no Valencian alternative. Spain is the only territorial political reference (Burguera, 1990; Guía, 1985). None of the possible national positions view the Valencian territory as autonomous, and the immense majority opt to identify with Spain.

\section{The Valencian social structure: territorial origins}

The construction of an alternative identity calls for the existence of an alternative social structure that is perceived as plausible. In the case of Valencia, there is a significant generational divide when it comes to definitions of nation. Specifically the Valencian population born after 1950 is more prone to discourse 
that is critical of the state. This is nothing special, given that it is normal for the younger generations to adopt more critical stances to the existing order; however, in this case, Valencian nationalism is practically non-existent in the population born before 1950 .

This is a consequence of the weak political projection of Valencian identity during the Renaixença (Renaissance) of the 19th century and during the Second Spanish Republic, which it brings us back to the 1970s. This was a decade when Valencian society underwent very significant changes to its social structure, particularly demographic and economic changes that caused an upheaval of traditional structures. Immigration, urbanisation, and industrialisation were very intense processes during these years, and a fraction of the Valencian elites began to question the definitions set forth by Spain. The decade began with the publication of "Nosaltres, els valencians" (We, the Valencians) by Joan Fuster (1962), marking a profound qualitative change in national reflection in Valencia. For the first time, there was an open presentation of the chance to create an alternative national discourse to that offered by the state, i.e., it is possible to be Valencian without being Spanish. Thus, promising Valencian discourses offering an alternative to Spanish identity are very young on a societal level.

This late development also helps us to understand the poor relationship between the territorial origin and the national position. In Valencia, it is the Valencians with ancestry in the region who maintain regional or unionist definitions, rather than those of Valencian nationalism. In fact, in terms of transmitting national definitions of reality to children, parents prefer to opt for the official Spanish definition, over the alternative which is barely experienced.

\section{The Valencian social structure: social classes}

Marx pointed out that national projects are an expression of the relationship between production and productive forces, of class relationships. This complex establishment of interests lays the material foundations for the formation of territorial alliances-those based on class. The purpose of these alliances is to preserve or improve existing production and consumption models, dominant technological combinations, social relationship patterns, levels of profits and salaries, business management technique and workforce quality, physical and social infrastructures, and the cultural qualities of life and work. Every single resident in a given territory may take an interest in influencing the future shape of the territory they inhabit (Harvey, 1985).

However, in Valencia we do not find these class alliances with a Valencian territorial base. The elites manifest a significant level of fragmentation in their definitions of the Valencian national reality. Business people adopt a mostly regionalist position, and in doing so they coincide with employees from the private sector, coinciding with the predominant definition of the Valencian population. However, the permanent salaried employees in the public sector (civil servants) find themselves closer to a Spanish unionist position. The field of economic relations and that of state structures lead us down different paths, and the position of Valencia's economic elites are not those the closest to unionism, but rather it is that of the political elite civil servants. This distribution locates the identity conflict in the sphere of bureaucracy itself, as it is also among the public workers where we find the largest presence of Valencian nationalists. Therefore, the difficulty in developing an alternative to the Spanish definition lies in the presence of the state structure itself, staffed mainly by workers with unionist views, rather than in the weakness of the Valencian business community which is certainly more inclined towards regionalist positions, hinting at the theory of the decapitation of Valencian society (Fuster, 1962; Mira, 1997).

\section{Language as an identifying trait}

Language usually plays a highly significant role in the construction of collective identities and in the Valencian case it assumes a crucial leading role (Ninyoles, 1969; Piqueras, 1996). The process of replacing Valencian with Castilian Spanish has progressed greatly since the 1960s, with prominent state intervention in the political, educational, and communicational systems. 
The use of Castilian Spanish was promoted in all these public spheres, with Valencian being confined to private use. Furthermore, in order to speed up the declining use of Valencian in the public sphere, the secessionism of Valencian has also been fostered, with anti-Catalan sentiment encouraged among the Valencian population.

The result is that in Valencia the key oral and written active skills in Valencian, i.e. knowing how to speak and write the language), are not what discriminate between national positions there. Specifically, they do not differentiate regionalist positions from unionist ones: both groups display diglossic behaviour in relation to Valencian (Ninyoles, 1971). It is only written skills, whether active (knowing how to write) or passive (knowing how to read), which establish distinctions, separating the nationalist Valencian positions from every other kind of Spanish identity, including regionalist identity.

This has important consequences in terms of the performativity of a possible alternative identity, and in structuring the field of symbolic relations. The written skills, which are more formal and acquired during schooling, are possessed by a small part of the Valencian population (the Valencian language was incorporated into the educational system in 1983, and a part of the population can also exempt themselves from learning it at school). However, active oral skills (knowing how to speak), are more widely distributed among the population. With this situation, in Valencia, the national conflict occurs between a minority that knows written Valencian and a majority that do not know it. In other words: Valencian national identity is not spoken in Valencian, it is only written, with the social effects that this has on its capacity for dissemination and circulation.

This division in skills leads us to linguistic secessionism and the self-interest dispute over Valencia-related legislation, which facilitates the rupture between oral and written skills, and hinders the link between Valencian language and a possible alternative national community to the Spanish one. Also, although the apparent value placed on Valencian is extremely low, it is the value dimension (opinions) and not the instrumental dimension (use), which discriminates between the different national positions. The relative instrumental lack of relevance of Valencian as an identity trait, can be explained due to the lack of appreciation of the collective identity linked to the use of the language. That is to say, in Valencia where you are from bears less weight than how you rate the Valencian language. This shows the lack of indifference and the high emotive triggering of linguistic attitudes, as an expression of the doubts that the language itself generates among the Valencian population, including (and most importantly) the Valencianspeaking population.

\section{Conflict regarding identity and performativity}

All this may seem highly contradictory, but indeed Josep Vicent Marqués previously stated that "Valencian reality is contradictory" at the start of his País Perplejo (1974, p. 11), outlining the existence of what he called a murky conscience, and what Ariño and Llopis call the Valencian anomaly (1993).

If we recall the definition of legitimation provided by Berger and Luckmann (1966, pp. 120-121), by Bourdieu and Wacquant (1992) or by Habermas (1973), the capacity for legitimation is achieved via the coincidence of cognitive schema and objective structures. We have just pointed out, for example, how attempts have been made to upset the cognitive definition of the language of Valencians in relation to its use and objective existence. Thus, discourses are constructed with legitimisation hurdles due to the dissonance between what they want to be and what they are, and the high level of emotive triggering stemming from this. The effect is that we not only find ourselves facing a conflict of identities but also a conflict about identities: what is being questioned is the legitimacy of the proposed national identities.

This lack of legitimacy reinforces performativity problems. Adherence to positions more in favour of their legitimacy does not represent the majority, especially positions defending a rift from the Spanish 
definition. With no legitimate nationalist discourse, there is no nation: the relative presence of the Valencian nationalist stance is low; however, unionism does not represent a majority position either as it is surpassed by regionalism.

Also, the general structure has not enabled the participation of Valencian nationalism in the creation of a socially predominant discourse. In fact, in País Valencià, unionists and regionalists account for around three quarters of the population; they engage in a conflict regarding the centralisation-decentralisation of the state, more than a national conflict. Therefore, Valencian nationalist discourse has been excluded from the field of relations, and as Bourdieu would assert, its symbolic capital has proven relatively insignificant.

In fact, up until very recently, it was practically impossible to predict the position on nationalism depending on associations with the political-party system; the Valencian parliamentary system does not express any national conflict (Beltrán, 1994; Franch, 1996; Mira, 1994). The lack of a stable Valencian parliamentary reference during the transition has made it difficult to perceive a Valencian political structure as a plausible alternative to the Spanish one. We cannot forget that the regional electoral limit of 5\% throughout the entire autonomous region has meant that when the Valencian nationalists have obtained parliamentary representation they have done so alongside a party from the state sector, with a Spanish definition of the Valencian reality.

\section{CONCLUSIONS}

Our conclusions lead us to put forward three arguments to explain the minimal impact achieved by alternative definitions to the one proposed by Spanish politics. These are arguments to which we must add the effects of state structural intervention on Valencian reality, with policies aimed at dismantling attributes with the potential to promote a desire for collective power, which might challenge the Spanish definition.

\section{Political vagueness}

In Valencia, apparently, language is the only attribute with a certain capacity for political construction. However, this capacity rests only on the assessment of the language expressed through opinions, and not on its public use. If language has an effective political function when used in the public sphere, among the Valencian population it fails to move beyond a secondary or potential role. Therefore, one of the effects of the diglossia has been to maintain the political function of language as an underlying force in the collective construction of Valencian society.

Secondly, among the Valencian population we do not find a proper territorial reference that has an impact on defining the policy for an alternative identity to the Spanish one. It is not the case that there is incompatibility between the Spanish territorial identification and the Valencian one; that does not exist. Rather, in the Valencian definition, the territory does not even come into play. This shortcoming also has devastating effects on the economic model and the destructive way in which the territory has been used, and also the lack of impetus in protests against the state in relation to issues such as funding or infrastructures.

Thirdly, we would like to add vagueness in relation to the construction of a them-and-us relationship between the people of Valencia and the other peoples belonging to the Spanish state. The most striking aspect is that the Valencian collective reference has no relevance, either positively or negatively, it simply does not come into play. Nor is there any negative collective reference for the rest of Spain, therefore we cannot detect others: from the Valencian point of view, in Spain we are all one. However, some positive references do appear that construct a hybrid Valencian us: between Catalan and Manchego identity. This result brings to mind the hypothesis of Mollà and Mira (1986) regarding the creolisation of Valencians. This is a hybrid construct which encourages more Spanish identification.

In terms of political definition, we therefore find ourselves with a language that has shadow effects (not effective ones), a non-existent territory and 
a Valencian us constructed out of a mixture of Catalan and Manchego identity, with no reference for otherness among the rest of the Kingdom of Spain. Could there be any greater political vagueness? As Fuster put it, "Neither meat nor fish".

Part of this vagueness can be attributed to the alternative discourse itself, to the extent that there are no significant differences between Valencian nationalism and the other groups, regarding the existence of a territorial unit in itself and the non-existence of a Valencian collective reference. The only language factor is a defined nationalist variable, and it stands out due to greater public use of Valencian, i.e. the political effectiveness of the language. However, this linguistic effectiveness does not significantly distinguish this group from regionalists. This confirms that a language without a territorial reference does not create a nation, but rather a region (Keating, 1996; Linz, 1985).

\section{A murky consciousness}

The murky consciousness is based in the high level of identification with the Spanish territory, the lack of linguistic appreciation of Valencian (diglossia), and the hybrid perception of identity itself. Thus, problems do not emerge so much with regard to what one wants to be, but rather in the perception of what one is. This is a kind of cognitive dissonance and the affected population is local: those that use Valencian as their mother tongue, those that use it on a regular basis, those that identify more closely with the Valencian territory, and those that express most sympathy for the Valencians. This clearly poses a question relating to the descriptive, pragmatic, and evaluative information that refers to identity itself.

It is worth highlighting an aspect deriving from this dissonance that is very important when it comes to determining the nationalist positions of Valencians: anti-Catalan prejudice (Bello, 1988; Flor, 2011). This prejudice operates within the framework of a murky consciousness and it especially affects the local population, and those with regionalist tendencies. Thus, while a lack of political definition was especially linked to nationalist Valencian positions, this cognitive contradiction is more linked to regionalist positions.

\section{The incompatibility between Valencian nationalists and regionalists}

The combination of vagueness and a murky consciousness has led to an incompatibility between the definitions of the Valencian reality between Valencia's nationalists and regionalists, with the backdrop of anti-Catalan sentiment. An insurmountable wall has separated them over the last few decades. As a consequence, in the Valencian case, regionalism has not been a pre-political stage for a possible alternative national identity, as Núñez points out (1998). In the Valencian case, the effect has been the opposite: regionalism has been a retaining wall holding back nationalism.

Indeed, territorial identification, the valuing of the Valencian language and anti-Catalan sentiment are dimensions that bring Valencian regionalists and nationalists into conflict with one another. This confrontation arises out of a combination of the vagueness of nationalist territory and the regionalist linguistic difference. This is a situation that will only be able to change if either territorial vagueness or linguistic dissonance are disabled, or even more so, if both are. In this regard, the Valencian nationalist movement has taken the most effective steps forward so far (Mezquida, 2015).

Ultimately, the combination of territorial vagueness, linguistic dissonance and anti-Catalan sentiment have contributed to the fact that, at present, alternative definitions to the Spanish one have not attained the social recognition required to pose a serious challenge to the state. Indeed, the Spanish proposal is one with devastating effects on the politics, economy, and culture of Valencian society. Indeed, one only has to look at the development of events and data over the last few decades, in each and every field relating to Valencian social structure. This devastation would have been more difficult to perpetrate if Valencian society had offered a stronger alternative to Spanish identity. 


\section{REFERENCES}

Anderson, B. (1983). Imagined Communities. Reflections on the origins and spread of nationalism. London: Verso.

Ariño, A., and Llopis, R. (1993). La Comunidad Valenciana: un problema de identidad. In Simposium Internacional Identidades colectivas en el mundo contemporáneo. Bilbao.

Barrera-González, A. (1997). Metodologies en l'estudi del nacionalisme. In Fundació Jaume Bofill (ed.), Nacionalismes i ciències socials (p. 239-248). Barcelona: Mediterrània.

Beck, U. (1998). La sociedad del riesgo. Hacia una nueva modernidad. Barcelona: Paidós.

Bello, V. (1988). La pesta blava. València: Tres i Quatre.

Beltrán, A. (1994). Un país impossible. Tavernes Blanques: Eixam.

Berger, P., and Luckmann, T. (1966). La construcció social de la realitat. Un tractat de sociologia del coneixement. Barcelona: Herder.

Bourdieu, P. (1977). Outline of a Theory of Practice. Cambridge: Cambridge University Press. doi: 10.1590/ S0103-20702013000100001

Bourdieu, P. (1979). La distinción. Criterio y bases sociales del gusto. Madrid: Taurus.

Bourdieu, P. (1980). L'identité et la représentation. Eléments pour une réflexion critique sur l'idée de région. Actes de la Recherche en Sciences Sociales, 35, 63-72. doi: 10.3406/arss.1980.2100

Bourdieu, P. (1994). Razones prácticas. Sobre la teoría de la acción. Barcelona: Anagrama.

Bourdieu, P., and Wacquant, L. (1992). Per una sociologia reflexiva. Barcelona: Herder.

Brubaker, R. (1996). Nationalism Reframed. Nationhood and the national question in the New Europe. Cambridge: Cambridge University Press.

Burguera, F. de P. (1990). És més senzill encara: digueu-li Espanya. València: Tres i Quatre.

Castells, M. (1997). La era de la información. El poder de la identidad. Madrid: Alianza.

Connor, W. (1994). Ethnonationalism. The Quest for Understanding. Princeton: Princeton University Press.

Flor, V. (2011). Noves glòries a Espanya. Anticatalanisme i identitat valenciana. Catarroja: Editorial Afers.

Foucault, M. (1996). Genealogía del racismo (Curso en el Collège de France 1975-76). La Plata: Editorial Altamira.

Foucault, M. (2006). Seguridad, Territorio, Población (Curso en el Collège de France 1977-78). Buenos Aires: Fondo de Cultura Económica.

Foucault, M. (2007). Nacimiento de la biopolítica (Curso en el Collège de France 1978-1979). Buenos Aires: Fondo de Cultura Económica.

Franch, V. (1996). Las elecciones del cambio: las autonómicas y municipales del 28 de mayo de 1995 en la Comunidad Valenciana. Revista Valenciana d'Estudis Autonòmics, 15, 101-260.

Fuster, J. (1962). Nosaltres els valencians. Barcelona: Edicions 62.

Geertz, C. (1973). Interpretación de las culturas. Barcelona: Herder.

Gellner, E. (1997). Nacionalisme. Catarroja: Editorial Afers.

Giddens, A. (1984). La constitución de la sociedad: bases para la teoría de la estructuración. Buenos Aires: Amorrortu.

Greenfeld, L. (1992). Nationalism: Five Roads to Modernity. Cambridge: Harvard University Press.

Guia, J. (1985). És molt senzill, digueu-li Catalunya. Barcelona: La Magrana.

Guibernau, M. (1997). Nacionalismes. L'Estat nació i el nacionalisme al segle Xx. Barcelona: Proa.

Habermas, J. (1973). Problemas de legitimación del capitalismo tardío. Buenos Aires: Amorrortu.

Habermas, J. (1976). La reconstrucción del materialismo histórico. Madrid: Taurus.

Hall, R.B. (1999). National Collective Identity: Social Constructs and International Systems. New York: Columbia University Press.

Harvey, D. (1985). The Urbanisation of Capital. London: Basil Blackwell.

Hechter, M. (1985). Internal Colonialism Revisited. En E. A. Tiryakian and R. Rogowski (eds.), New Nationalisms of the Developed West. London: Allen \& Unwin. 
Hechter, M. (1989). El nacionalismo como solidaridad de grupo. In A. Pérez-Agote (ed.), Sociología del nacionalismo. Bilbao: Universidad del País Vasco.

Hroch, M. (1985). Social Preconditions of National Revival in Europe. Cambridge: Cambridge University Press.

Keating, M. (1996). Naciones contra el Estado. El nacionalismo de Cataluña, Quebec y Escocia. Barcelona: Ariel.

Lamo de Espinosa, E. (1990). La sociedad reflexiva. Sujeto y objeto del conocimiento sociológico. Madrid: CIS.

Larrain, J. (1994). Ideology and Cultural Identity. Cambridge: Polity Press.

Linz, J. J. (1985). From Primordialism to Nationalism. In E.A. Tiryakian and R. Rogowski (ed.), New Nationalisms of the Developed West. London: Allen \& Unwin.

Lukes, S. (2005). Power: a radical view. New York: Palgrave-Macmillan.

Máiz, R. (1997). Nacionalismo y movilización política: un análisis pluridimensional de la construcción de las naciones. Zona Abierta, 79, 167-216.

Marqués, J. V. (1974). País Perplex. València: Tres i Quatre.

Mezquida, A. (2015). El valencianisme enfront Espanya. Una anàlisi estratègica. Barcelona: Fundació Nexe.

Mira, J. F. (1994). Hèrcules i l'antropòleg. València: Tres i Quatre.

Mira, J. F. (1997). La nació dels valencians. València: Tres i Quatre.

Mollà, J. D., and Mira, E. (1986). De Impura Natione. València: Tres i Quatre.

Moreno, L. (1997). La federalización de España. Poder político y territorio. Madrid: Siglo XXI.

Morin, E. (2004). Introducción al pensamiento complejo. Barcelona: Gedisa.

Ninyoles, R. L. (1969). Conflicte lingüístic valencià. València: Tres i Quatre.

Ninyoles, R. L. (1971). Idioma i prejudici. València: Tres i Quatre.

Núñez, X. M. (1998). Movimientos nacionalistas en Europa. Siglo xx. Madrid: Síntesis.

Oommen, T. K. (1995). Contested Boundaries and Emerging Pluralism. International Sociology, 10(3), $251-268$.

Pérez-Agote, A. (1989). Hacia una concepción sociológica de la nación. In A. Pérez-Agote (ed.), Sociología del nacionalismo. Bilbao: Universidad del País Vasco.

Pérez-Agote, A. (1993). Las paradojas de la nación. Revista Española de Investigaciones Sociológicas, 61, 7-22.

Pérez-Agote, A. (1995). Nación y nacionalismo. In J. Benedicto and M. L. Morán (ed.), Sociedad y Política. Temas de sociología política (p. 109-138). Madrid: Alianza.

Piqueras, A. (1996). La identidad valenciana. Madrid: Escuela Libre Editorial.

Rogowski, R. (1985). Causes and Varieties of Nationalism: a Rationalist Account. In E. A. Tiryakian and R. Rogowski (ed.), New Nationalisms of Developed West (p. 87-108). London: Allen \& Unwin.

Rokkan, S. (1975). Cities, States and Nations: A Dimensional Model for the Study of Contrasts in Development. In S. N. Eisenstadt and S. Rokkan (ed.), Building States and Nations (p. 73-98). Beverly Hills: Sage Publications.

Rokkan, S., and Urwin, D. W. (1983). Economy, Territory, Identity. Politics of West European Peripheries. London: Sage Publications.

Sack, R. D. (1986). Human Territoriality: Its Theory and History. Cambridge: Cambridge University Press.

Sewell, W. H. (1992). A Theory of Structure: Duality, Agency and Transformation. American Journal of Sociology, 98(1), 1-29.

Shils, E. (1957). Primordial, personal, sacred and civil ties. British Journal of Sociology, 7, 113-145.

Simmel, G. (1908). Sociología. Estudios sobre las formas de socialización. Madrid: Alianza.

Smith, A. D. (1986). The Ethnic Origins of Nations. Oxford: Basil Blackwell.

Smith, A. D. (1989). The Origins of Nations. Ethnic and Racial Studies, 12(3), 340-367.

Soja, E. W. (1985). The Spatiality of Social Life: Towards a Transformative Retheorisation. In D. Gregory and J. Urry (ed.), Social Relations and Spatial Structures (p. 90-127). London: Macmillan.

Sztompka, P. (1993). Sociología del cambio social. Madrid: Alianza Editorial.

Tarrow, S. (1994). El poder en movimiento. Los movimientos sociales, la acción colectiva y la política. Madrid: Alianza Editorial. 
Therborn, G. (2000). At the birth of second century sociology: times of reflexivity, spaces of identity, and nodes of knowledge. British Journal of Sociology, 51(1), 37-57.

Tilly, C. (1984). Grandes estructuras, procesos amplios, comparaciones enormes. Madrid: Alianza.

Tiryakian, E. A., and Nevitte, N. (1985). Nationalism and Modernity. In E. A. Tiryakian and R. Rogowski (ed.), New Nationalisms of the Developed West (p. 57-86). London: Allen \& Unwin.

Tivey, L. (1981). El Estado nación. Barcelona: Península.

Villasante, T. R. (2000). Algunas diferencias para un debate creativo: abriendo una nueva etapa para el Network Analysis. Política y Sociedad, 33, 81-95.

Weber, M. (1922). Economía y sociedad. México: Fondo de Cultura Económica.

\section{BIOGRAPHICAL NOTE}

Rafael Castelló-Cogollos has a PhD in Sociology (University of Valencia) and is an Associate Professor in the Department of Sociology and Social Anthropology at the University of Valencia (1989). He has worked specifically on issues related to national identity, linguistic practices, demographics, and political sociology with reference to Valencia and has participated in several collective projects analysing the Valencian social structure. 